す場合，その討数值は被検体の厚さにより指数関数的に 減薣するため，厚さに対して直線関係を示さず，シンチ グラムより厚さを想像するととは困難である.今回高さ $25 \mathrm{~cm}$, 底辺 $25 \mathrm{~cm}$ ，幅 $8 \mathrm{~cm}$ ，の正三角形汃らなる Mix-D ファントームをスキャニングし，その計数值をフェライ ト・コアー・メモリュニットに蓄積する，蓄積データー は HITAC-5020 により刘数区分を行ないシンチグラム を得た結果厚さに相関した像を得るととが出来た。

\section{1. 試作小児用レノグラム装置について} 東京慈恵会医科大学附属病院放射線科。 ○榊 徳市・川軧 健一・井下゙ 英慧

[目的]

乳幼児領域の renogram 検查での曲線評価において， 解析結果が成人と異った值を示し，乙れが成人と0生理 学的, 解剖学的差異によるものとあ考えられていた。我 我は今回乳幼罢領域の検查に適した検出器を試作使用し, 成人と殆えど変らぬ結果を得たので報告する.

[方法]

検出部は 1 "×1”の NaI (Tl) の crystal と外形 $6.9 \times 8$ $\times 13 \mathrm{~cm}$, 閪口部 $31 \times 42 \mathrm{~mm} の$ collimetor 使用, preamp 《検出器外に設翼した。

\section{[考察亚に結論]}

小児用検出部を使用した renogram 検查での幽線評価. parameter 值は成人之殆えど変ら植であり, 從来の乳 幼児領域での renogram 解析での不充分な原因が，检出 器, collimmtor が不適合であったと推測された。

\section{2. シャドウシールド型ヒューマンカウンタの基礎的} 実験

大阪大学潪学部附属获院 RI 実験室 ○猪熊 正克 放射線科

久住 佳三・代藤 慎弥 池原 勝広・速水 炤宗

中レベルの性能を持つヒューマンカウンタの概要を報

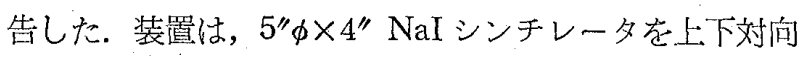
にし，被測定者はその間を移動するととで全身のRI 量 を測定する.コリメータは，フラットフィールドとスリ

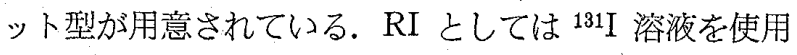
した．主な性能 (1) RI 濃度乙計数の直線性は $100 \mu \mathrm{Ci}$ / $10 \mathrm{~m} l$ 迄良好, (2) 最小検出限界は, 点線源で 10 分計測の 場合 $0.014 \mu \mathrm{Ci}$ ，等身大線源で $15 \mathrm{~cm} /$ 分棓測の場合 0.070

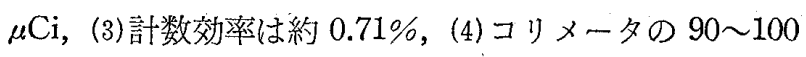
領域はフラットフィールド型では空気中でスキャン方向 $25 \mathrm{~cm}$, 上下方向 $7 \mathrm{~cm}$ 水中で $20 \mathrm{~cm}, 5 \mathrm{~cm}$ ，スリット型で
は空気帆，水中共にスキャン上下方向 $5 \mathrm{~cm}$ である，臨床 上のトレーサー法を主目的とする中レベルの性能を有す ると思われる。

\section{質問}

等感度曲線に烠々た ${ }^{131} \mathrm{I}$ の点線源 $10 \mu \mathrm{Ci}$ の作成方法 について.

(福岡望田太門)

答

等感度菂線を雉成するに際して使用した点線源は，市 販のガラス管内徍約 $1 \mathrm{~mm} \phi$ のむのに, RI 溶液 $0.1 \mathrm{~m} l$ を 入れ，西らかじめ片側を密封して和き，溶液注入後に片 側を，方販の接着剤（アラルダイト）によっ封印し，24 時間に使用した。

123. 当院におけるRI データー処理オンラインシステム 珓大禔院放射線科

○久住 佳三・猪熊 正克・速水 俯宗 段床 嘉腈・增田一孝

[目的]

プログラム内蔵方式のデーター姏理技術を主体とした RI データー观理システムについて紹介する.

レノグラム装置 $(4 \mathrm{CH})$ ，シンチスキャナー，ヒュー マンカウンター等 RI 計测装置に接続してオンラインで RI データーを収集，狸，表示するるので処理機能己 しては，データーの作成，収集，蓄積のほ办に，スム一 ジング，微分，積分，エンファシス，その他のプログラ ムを内蔵して扣り, 表示方式としては，一次元断面表示， 2 次元輝度変調, 3 次元鳥汃ん図表示, タイプライター による印字, 紙テープによるさん孔等の機能を有してい る:とれらは非常に利用度が高く，又オフラインにて大 型コンピューターを使用できるが，小型コンピューター 用処理方法の開発が急がれる。

\section{座長集約}

最近核医学部門の進歩普及はめざましく，Invitro 検 查は勿論, Invivo 検查に扎坑す,シンチスキャナ一の

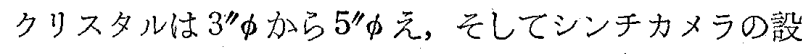
置, RI データー処理装置の導入と, いよいよ大型化の 傾向にある. 今回の研究登表むその傾向をよく反映して いる.

シンチカメラに関する発表では, 固有分解能, コリメ 一夕付きでの分解能, 腫瘍検出能など形態検査に直接関 係する研究は，だんだん問題点を掘り下げてきている。 しかし，シンチカメラの利点を生かした動態検查に関す る発表が一題もなかったのは残念である。

小罗の Renogram 用コリメータの註作発表は，地踈 ではあるがシンチカメラのような動態検查可能な装置を 
あたない施設にとっては大変ありがたいととである.

また，臨床分野においてす利用範囲の広い全身計測装 置は特に興味深いものであり，今後の研究に期待を寄せ たい.

RI データ処理システムの紹介が 1 例あったが，次年 度には具体的成果についての発表をお願いしたい。

以上概略を述べたが，シンチカメラについては装置別 の性能（解像力, 直線性, 均一性, 感度など) を統一し た条件で調べてみるととも興味ある事項である，基礎的 串験に関してはデータのデイジタル化により，より客観 的になるであろう。これはデータ処理装置の導入によっ て比較的容易に施行できる.

この様な基礎研究のみならず，一般们に核医学検查に たずさわる者は，データの処理技術の修得が急務ではな かろうか。奈たシンチカメラ等の普及により，短半減期 核種の利用がふえ，術者の被曝汇関する問題が増大して くるととも忘れてはならない。(注：演題120番は都合で RI 3のグループで発表された）

\section{R.I 3 座長 岡本日出夫}

124. Res-O-Mat $T_{4}$ および Thyopac- $T_{3}$ Kit の使用経験 東北大学附属病院放射線部

○今野 秀穂・中村 護・沢井 義一

125. 甲状腺機能検查における所謂 $T_{7}$ Value についての 検討

住友病院 RI 室

○金尾 啓右・本田 稔

Isotope を利用した血中甲状腺ホルモン量測定法とし ては， $\mathrm{T}_{3} \mathrm{RSU}$ (トリオソルブテスト)， $\mathrm{T}_{4}$ test（テト ラソルブテスト) 功あるが， $\mathrm{T}_{3}$ 值 $\times \mathrm{T}_{4}$ 値として算出さ れる $T_{7}$ Value について検傠を行なった結果， $T_{3}$ 值単独 と $\mathrm{T}_{7}$ Value の比較に扔いてあ， $\mathrm{T}_{4}$ 值単独と $\mathrm{T}_{7}$ Value の比較に执いても $T_{7}$ Value がかな正確に甲状腺機能 を反咉するととを認めた。同時に甲状腺疾患治療中の各 值の変動を見たが，甲状腺機能九進症，甲状腺機能低下 症（原発性）のいづれす $\mathrm{T}_{7}$ Value は $\mathrm{T}_{3} \cdot \mathrm{T}_{4}$ 值に比し て動摇が少なく，治裺経過とほぼ平行して正常化した。 この成績は， $T_{7}$ Value が治療効果判定の上からも有用 であるととを示唆しているものと思われる。

126. レジンストリップによる U.I.B.C 測定用キットの使 用経験

順天堂大学医学部附属病院アイソトープ診療室 ○関 守雄・宮崎正道・松、田茂
化学療法研究所附属病院放射線室

林 太郎

\section{質問}

インキュベーションにおける温度による影響，並びに 時間によって, 特にローテータの回転数にようて測定值 が変動しないか，温度による測定值の変動を少くするた めに，測定時の温度変動は，どの程度ゆるされるのか。

（関西 猪熊正克）

\section{答}

我々の使用したローテーターは33回転であった．回転 数が大巾に増加すれば当然時間は岗る程度短縮する事は 出来ると思う。

今回の実験は温度差を $15 \sim 20^{\circ} \mathrm{C}$ 亿って実験した．至 適温度は $20^{\circ} \mathrm{C}$ であり $\pm 2^{\circ} \mathrm{C}$ 位ではその值に大差なく実用 的には問題はないと思う。

127. ${ }^{67} \mathrm{Ga}$-Citrate の使用経験と基礎的考察

日本医科大学附属第一病院放射線科

○根津 伸弘・山岸 一雄・池田 幸好

\section{質問}

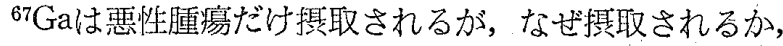
そのメカニズムを御知らせ下さい，（福島 竟藤 勝） 答

${ }^{67 G a-c i t r a t e}$ の再瘍に取り込ま机るメカニックは，核 医学会であ，かなり討論をされておりますがままだ十分 な結諭を見られていない様汇思われますし，私共の病院 ではそれについての実験は行っておりません。

128. LINACによる Ga 核種の生産と Carrier-free ${ }^{67} \mathrm{Ga}$ Citrate による腫瘍診断の基礎的臨床的研究 東北大学抗酸菌病研究所放射線医学研究 ○位藤多智雄・二瓶 茂 安斎 貞雄・营原 康博 仙台厚生病院放射線科 佐藤 新平

[目的]

1. LINAC による Ga 核種の生産実験。

2. Carrier-free ${ }^{67} \mathrm{Ga}$-Citrate を使用しての悪性腫煌 の基礎的及び郘床的研究。

〔方法]

東北大学核理研沉より Germanium を Target として 照射し Ga 核種を生産した。基礎は家鬼癌を大腿部门移 殖し， ${ }^{67} \mathrm{Ga}$ の血中消失，腫崵及び各種臟器の経日的摂取， 又炎症菓摄取率。臨床例は血中消失，尿中，屎中排泄， 肺癌，肺化膿症などのスキャニング.

[結果】 